DOI:10.14258/tpai(2021)33(3).-04

УДК 903«632»

\title{
ADVANTAGES OF SCAR-PATTERN ANALYSIS IN THE STUDY OF PALEOLITHIC CORES
}

\section{Alena V. Kharevich, Kseniya A. Kolobova*, Andrey I. Krivoshapkin}

Institute for Archaeology and Ethnography, Siberian Branch, Russian Academy of Sciences, Novosibirsk, Russian Federation

ORCID: https://orcid.org/0000-0002-2267-2452, e-mail: aliona.shalagina@yandex.ru

ORCID: https://orcid.org/0000-0002-5757-3251, e-mail: kolobovak@yandex.ru

ORCID: https://orcid.org/0000-0002-5327-3438, e-mail: krivoshapkin@mail.ru

\section{*Corresponding author}

Abstract: Scar-pattern or working step analysis is one of the main components of technological analysis. This analysis is usually applied to reconstruct the technological sequence of Middle and Upper Palaeolithic bifacial tools. In addition to bifacial implements, the scar-pattern analysis is applied to geometric microliths and to macro-implements made on large flakes, such as Quina scrapers. However, the potential of this analysis is much wider. Here we present the basic approaches and algorithm for the application of scar-pattern analysis to core analysis.

The analysis algorithm includes five main research activities: determining the directions of all negatives, determining the mutual sequence of adjacent negatives, combining negatives into "technological units", determining the mutual consistency of the groups of combined negatives and complicating of scheme. As an example, two carinated technological sequences in the Kulbulakian from Western Central Asia are provided. Scar-pattern analysis applied to reconstruct the technological sequences of the cores is devoid of the disadvantages inherent in this analysis applied to bifacial tools. We believe that scar-pattern analysis is the most promising in Paleolithic technological reconstructions.

Keywords: scar-pattern analysis, working step analysis, cores, technology, knapping

Acknowledgements: The research has been supported by Russian Foundation for Fundamental Research, project №19-09-00453 and the R\&D Project No. 0329-2019-0002 “The Oldest Cultural Processes in Central Asia“.

For citation: Kharevich A. V., Kolobova K. A., Krivoshapkin A. I. Advantages of Scar-Pattern Analysis in the Study of Paleolithic Cores. Theory and Practice of Archaeological Research. 2021;33(3): 68-80. (In English). DOI: 10.14258/tpai(2021)33(3).-04

\section{ПРЕИМУЩЕСТВА АНААИЗА ПОСАЕАОВАТЕАЬНОСТИ СКОАОВ ПРИ ИЗУЧЕНИИ ПААЕОАИТИЧЕСКИХ НУКАЕУСОВ}

\section{А. В. Харевич, К. А. Колобова*, А. И. Кривошапкин}

Институт археологии и этнографии СО РАН, г. Новосибирск, Российская ФеАерация

ORCID: https://orcid.org/0000-0002-2267-2452, e-mail: aliona.shalagina@yandex.ru

ORCID: https://orcid.org/0000-0002-5757-3251, e-mail: kolobovak@yandex.ru

ORCID: https://orcid.org/0000-0002-5327-3438, e-mail: krivoshapkin@mail.ru

*КорреспонАирующий автор

Резюме: Анализ последовательности сколов является одним из основных компонентов технологического анализа. Этот анализ обычно применяется для реконструкции технологической 
последовательности бифасиальных орудий среднего и верхнего палеолита. Помимо бифасиальных орудий, анализ последовательности сколов применялся к геометрическим микролитам и макроорудиям, изготовленным на крупных отщепах, таким как скребки кина. Однако потенциал этого анализа гораздо шире. В предлагаемой вниманию читателей статье мы представляем основные подходы и алгоритм применения анализа последовательности сколов для анализа палеолитических нуклеусов.

Алгоритм анализа включает пять основных шагов: определение направлений всех негативов сколов на артефакте, определение взаимной последовательности соседних негативов сколов, объединение негативов в «технологические единицы», определение взаимной последовательности групп объединенных негативов и создание финальной схемы. В качестве примера приведен анализ последовательности сколов на двух кареноидных нуклеусах из комплексов кульбулакской культуры (западная часть Центральной Азии). Анализ последовательности сколов, примененный для реконструкции технологических последовательностей нуклеусов, лишен недостатков, присущих этому анализу применительно к бифасиальным орудиям. Авторы считают, что анализ последовательности сколов является наиболее перспективным в реконструкции палеолитических технологий первичного расщепления.

Ключевые слова: анализ последовательности сколов, анализ технологических этапов, нуклеусы, технология, первичное расщепление

Благодарности: Исследование выполнено при поддержке Российского фонда фундаментальных исследований, проект №19-09-00453, и научно-исследовательского проекта №0329-2019-0002 «Древнейшие культурные процессы в Центральной Азии».

Для изитирования: Харевич А.В., Колобова К.А., Кривошапкин А.И. Преимущества анализа последовательности сколов при изучении палеолитических нуклеусов // Теория и практика археологических исследований. 2021. Т. 33, №3. С. 68-80. DOI: 10.14258/tpai(2021)33(3).-04

Tntroduction

The application of the "chaîne opératoire" [Boeda et al., 1990; Pelegrin, 1990; Pigeot, 1991; Inizan et al., 1999] and all its components have in recent years become an integral part of Palaeolithic research. The approach from the French research practice, aimed at a comprehensive reconstruction of the technological sequence is now actively used in Russian [Girya, 1997; Nekhoroshev, 1999; Pavlenok, Belousova, Rybin, 2011; Kolobova, 2006] and English-speaking [Bar-Yosef, Van Peer, 2009] research literature. One element of this procedure is scar-pattern analysis, along with attributive analysis, experimental and use-wear, refitting, and the method of raw material units.

The idea of a scar-pattern analysis is to reconstruct the knapping process of a lithic implement by examining all the negatives and ridges on its surface and determining their mutual consistency. As an independent research tool, this method was first applied by J. Richter and A. Pastoors in their study of Middle Palaeolithic bifacial tools. The basic principles of the method have been formulated and substantiated in the research works of A. Pastors [Pastoors, Schafer, 1999; Pastoors, 2000], J. Richter [2001], E. Boeda [2001], M. Kot [2013].

The applicative method is considered to be the most reliable method for identifying the main stages of stone artefact manufacture. However, the application of this method is not possible in all Paleolithic complexes. In such a situation, the use of scar-pattern analysis becomes particularly important, as a set of negatives on the surface of a stone artefact provides direct evidence in identifying methods and ordering the procedures used in its manufacture. 
One of the most widespread categories of artefacts that can provide important information about knapping technology in the absence of refitting is cores. The advantages of using scarpattern analysis in the study of cores are the subject of this article.

\section{Historiographical review}

The basic principles of scar-pattern analysis were originally developed and used extensively in the study of bifacial tools. This is because the application of the refitting, as the most reliable method for reduction process reconstructing, is not possible in the case of bifacial tools, with a few exceptions [Veselsky, 2008; Nerudova, Neruda, 2017; Wiśniewski et al., 2020]. Bifacial implements were often used as multi-purpose tools and were used as mobile raw materials [Uthmeier, 2004], which were brought to the site being shaped [Chabai, 2004]. In the research literature there are many successful examples of reconstruction of bifacial tool production through scar-pattern analysis [Richter, 2004; Uthmeier, 2012; Joris, 2006; Kot, 2013; Shalagina et al., 2020].

Today, scar-pattern analysis is used to reconstruct the technological sequences of different lithic artefacts, including various types of tools made of blanks. In particular, the use of scarpattern analysis made it possible to reconstruct the technological sequence of the production of truncated faceted tools in the complexes of Obi-Rakhmat rock shelter (Uzbekistan), and to determine that the purpose of the these tools production was to create a working edge, and not to obtain blanks [Shalagina, Krivoshapkin, Kolobova, 2015; Shalagina, Kolobova, Krivoshapkin, 2019].

This analysis has no limitations in terms of the tool size and the intensity of their design. The analysis proves effective both in the study of microliths and various macro-tools. The study of early geometric microliths in Central Asia, allowed the authors to identify general patterns in the design of microliths by analyzing the chronological sequence of retouch facets [Kolobova, Krivoshapkin, Shnaider, 2018]. A successful example of the application of scar pattern analysis to macro-tools produced on blanks is the study of the earliest "Quina" and "semi-Quina" type scrapers in the Qesem Cave, in the Middle East. Using scar pattern analysis in conjunction with use-wear analysis allowed the researchers to identify several cycles of processing and use of scrapers [Lemorini et al., 2015].

\section{Application of scar-pattern analysis to the study of cores}

Recently, scar-pattern analysis has increasingly been used to reconstruct the knapping process. It is not always used as an independent research tool, however, the study of negatives from removals are actively used in the analysis of cores.

Detailed examination of the negatives on the surface of the cores allows information to be extracted on the size of the withdrawals, the impact force and type of indenter, the procedures used to shape the nucleus and the way the impact pad was designed. Detailed examination of the negatives on the core surface provides information on the size of the removed flakes, the impact force and type of the hammer, the procedures used to core shaping and the way the striking platform was designed. In general, the negatives on the cores are highly informative regarding the reconstruction of knapping patterns. The morphology and size of the negatives can be analysed either manually or with special equipment and software that automates the process [Clarkson, Vinicius, Lahr, 2006; Kolobova et al., 2020]. First and foremost, scarpattern analysis is used to reconstruct the main stages of core knapping, as well as the patterns 
associated with the design of striking platforms and the core front [Soriano et al., 2015; Pavlenok, Kozlikin, Shunkov, 2021]. Often, reduction schemes based on a detailed study of the negatives are a good illustration of the technological process and the conclusions reached through technological analysis [Zwins, 2012]. Analysis of the morphology of the negatives on the cores also makes it possible to reconstruct the length of the pre-form during the previous reduction stages, as well as the volume of the material chunk. The cores contain both the complete negatives of the impact point and their distal or medial fragments. Nevertheless, even examining fragments of the negatives provides information about the initial size of the obtained flakes. Counting method was proposed by P. Neruda for analyzing Middle Paleolithic and Upper Paleolithic cores. This method is based on calculating the initial length of the removed flake by measuring the wave of the impact on its negative. The effectiveness of this method has been confirmed on both experimental and archaeological assemblages [Neruda, 2015].

In Russian Palaeolithic studies, the ideas of analysis of removal negatives began to be developed from the middle of the $20^{\text {th }}$ century within the framework of morphological [Lyubin, 1965], and then the concept of dynamic technological [Doronichev, 1986] analysis of cores. In contemporary science, scar-pattern analysis is applied in the definition of "flaking systems" in the process of reconstructing knapping technology [Nekhoroshev, 1999]. In this case, the "flaking system" refers to a set of negatives reflecting a particular stage in the design of a stone artefact (cores, core fragments and bifacial tools). One "flaking systems" is a combination of an striking platform and its corresponding core surface [Ocherednoy, 2014, p. 215-221].

\section{Research procedure for scar-pattern analysis}

Regardless of the artefacts being studied, the research procedure for scar-pattern analysis is unified and is a process consisting of several steps, each of which is depicted in graphic schemes 3. combining negatives into "technological units" [Pastoors, 2000] or "blank sequences" [Kot, 2013].

1. Determining the directions of all negatives, on the surfaces of the artefact (Fig. 1.-a);

2. Determining the mutual sequence of adjacent negatives (Fig. 1.-b);

3. Combining negatives into "technological units" [Pastoors, 2000] or "blank sequences" [Kot, 2013]. Here, a "technological unit" refers to a group of negatives with similar morphological characteristics (from the same striking platform, in the same direction, etc.) and aimed at the same technological task. o simplify visual perception, each such technological unit is indicated by a separate color and letter in the graphic illustration of the artefact (Fig. 1.-c).

4. Determining the mutual consistency of the groups of combined negatives, and its graphical representation (Fig. 1.-d). Determines the interdependence and sequence of the design of the different surfaces (parts) of the artefact. At this stage, the chronological scheme of the artefact's design is reconstructed.

Different ways of representing the results of analysis exist [Richter, 2001; Jöris, 1994; Kot, 2014]. In our paper, in a simplified, adapted version, we use the event chain process diagram (EPC diagram) adopted for modelling economic phenomena [Scheer, 1998]. It is a type of flowchart that is an ordered combination of events, where each event is defined by a different time frame and mutual influence. 


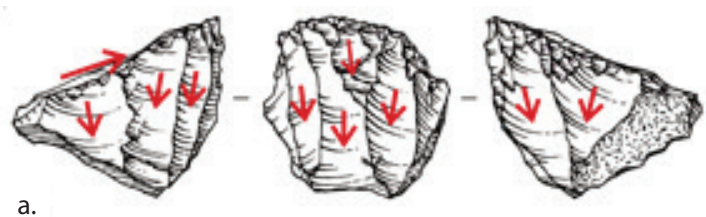

a.

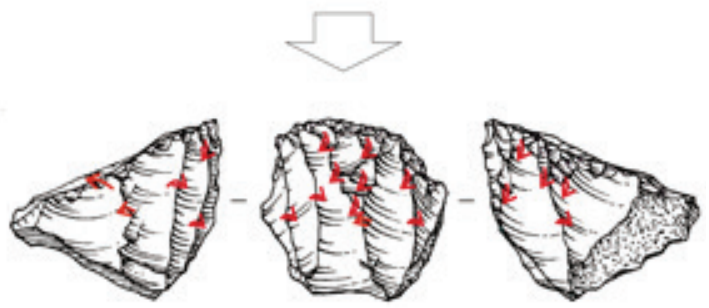

b.
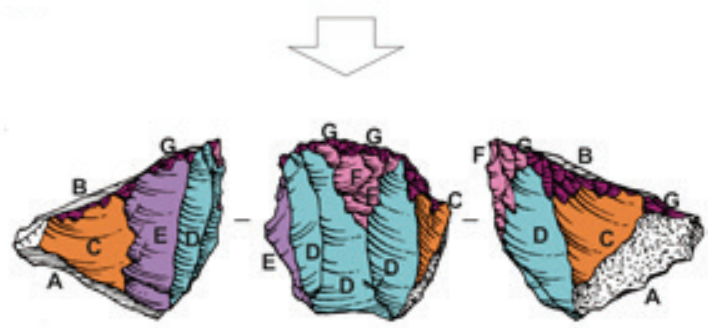

c.

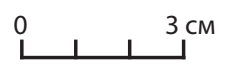

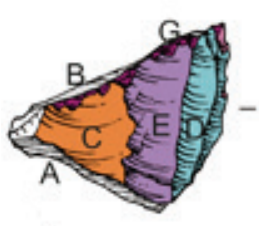

d.

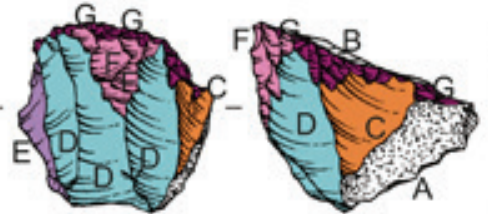

$3 \mathrm{CM}$

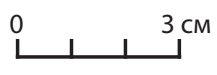

Fig. 1. Procedure of scar-pattern analysis: a - determining the directions of negatives on artifact;

$b$ - determining the mutual sequence of adjacent negatives; $c$ - combining negatives into

"technological units"; d - completed scheme of scar-pattern analysis

Рис. 1. Процедура анализа последовательности сколов: а - определение направлений негативов на артефакте; $b$ - определение взаимной последовательности соседних негативов;

c - объединение негативов в «технологические единицы»;

$d$ - завершенная схема анализа последовательности сколов

5. At the final stage of analysis, the entire production process is divided into phases based on the compiled scheme. As a result of the analysis of all the negatives on the surface of the 
artefact, a scheme of its design is constructed, highlighting the main technological steps (Fig. 1.-d). Thus, by systematising the negatives in chronological order, visible on the surface of the artefact, the place of the individual technological steps in the reduction process is determined.

The example of the application of scar-pattern analysis to the study of cores

To illustrate the application of scar-pattern analysis in the reconstruction of primary reduction process we give an example of carinated cores from the Kulbulakian Upper Paleolithic complexes of Central Asia. The use of scar-pattern analysis in this case makes it possible to demonstrate the technological differences between the two different concepts within a carinated technology.

The following technological sequence is reconstructed within the framework of the concept of carinated end-scrapers. As a rule, massive flakes were used as blanks for such cores.

The first stage in the reduction of the carinated end-scrapers was to select the striking platform (in the case of the ventral surface), or to create one (Fig. 2). The next step was to prepare the main flaking surface by removing a series of flakes from the striking platform, creating a convex front surface (Fig. 2). This was followed by the realization of the target blanks - bladelets with a curved profile. The reduction sequence involves recurrent removal of the bladelets without the realization of technical spalls at the core processing stage.

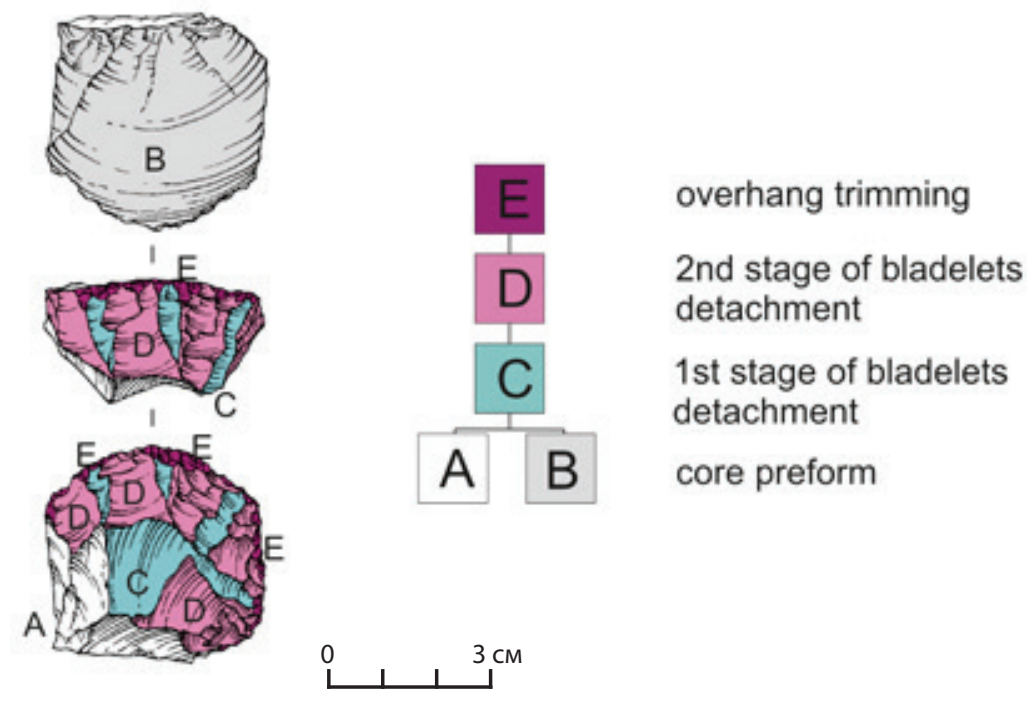

Fig. 2. The example of scar-pattern analysis on carinated (end-scraper) core from Kulbulakian Upper Paleolithic assemblage

Рис. 2. Пример анализа последовательности сколов на кареноидном нуклеусе (кареноидном концевом скребке) из Кульбулакского верхнепалеолитического комплекса

The second technological sequence is based on the processing of small chunks, or blanks, oriented so that the ventral and dorsal surfaces act as left and right laterals of the core. As part of the main core reduction, a series of targeted bladelets was removed from a small area of the front bounded by the negatives of the lateral removals (Fig. 3). 


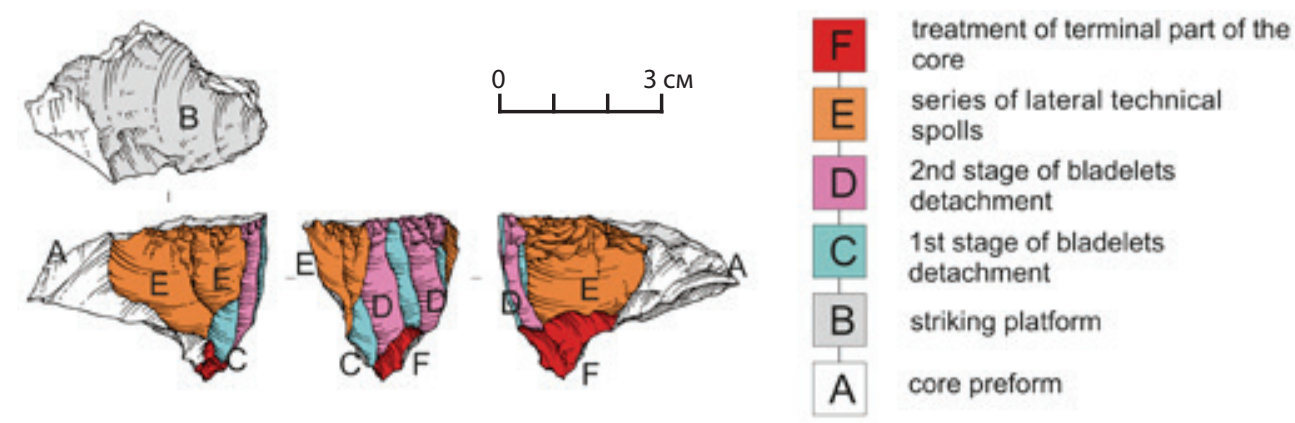

Fig. 3. The example of scar-pattern analysis on carinated (lateral) core from Kulbulakian Upper Paleolithic assemblage

Рис. 3. Пример анализа последовательности сколов на кареноидном нуклеусе (латеральном кареноидном нуклеусе) керне из Кульбулакского верхнепалеолитического комплекса

In this case, the use of scar-pattern analysis made it possible to reconstruct the different technological sequences of core reduction within a single carinated technique, which could not be done on the basis of technical-typological analysis.

\section{Conclusion}

Scar-pattern analysis is a versatile tool for the most accurate reconstruction of different technological sequences. Typically used to analyze bifacial tools, this can seem overly complicated and time-consuming to inexperienced researchers. However, this perception is solely a consequence of complex reductionist patterns of production and further biface rejuvenation.

The application of the scar-pattern to core analysis is able to provide new, previously inaccessible technological data. The hierarchical flaking inherent in the Levallois technology has enabled one of the earliest manifestations of this technology in the Lower Paleolithic of Europe to be justified [Soriano, Villa, 2017].

Scar-pattern analysis of the cores from layer 23 of the Kulbulak site provided evidence of a much larger portion of Levallois technology in the Middle Paleolithic of western Central Asia than previously assumed. Scar-pattern analysis of the bladelet cores demonstrated technological similarity with Levallois cores [Pavlenok G., Pavlenok K., 2019].

As our practice shows, the use of scar-pattern analysis has substantial prospect because the cores usually have simpler reduction patterns that even a non-experienced researcher can read. An undoubted advantage of using scar-pattern for core analysis is that it provides more accurate technological data than the widespread technological or attribute analysis.

\section{REFERENCES}

Bar-Yosef O., Van Peer P. The Chaine Operatoire Approach in Middle Paleolithic Archaeology. Current Anthropology. 2009. № 1 (50). Pp. 103-131.

Boëda E. Determination des unités techno-fonctionnelles des pièces bifaciales provenant de la couche acheuléenne C'3 base du site de Barbas I // Les industries à outils bifaciaux du 
Paléolithique moyen d'Europe occidentale. Liège : Editions de l'Université de Liège 2001. Pp. 51-75.

Boëda E., Geneste J. M., Meignen L. Identification de chaîne opératoires lithiques du Paléolithique ancien et moyen // Paléo. 1990. № 2. Pp. 43-80.

Chabai V.P. Srednij paleolit Kryma [Middle Paleolithic of Crimea]. Simferopol : Shlyah, 2004. 324 p. (In Russ.)

Clarkson C., Vinicius L., Lahr M. M. Quantifying Flake Scar Patterning on Cores Using 3D Recording Techniques // Journal of Archaeological Science. 2006. № 33. Pp. 132-142.

Girya E. Yu. Tehnologicheskij analiz kamennyh industrij: Metodika mikro-makroanaliza drevnih orudij truda. Ch. 2 [Technological Analysis of Stone Industries (Methodology of micro-macroanalysis of Ancient Tools, Part 2). Sankt-Peterburg : Izd-vo IIMK RAN, 1997. C. 199 (In Russ.)

Doronichev V. B. Izuchenie tehniki rasshchepleniya nukleusov kak sistemy vzaimosvyazannyh teknologicheskih processov (po materialam Abadzehskogo mestonahozhdeniya v Majkopskom rajone) [Studying the Technique of Splitting Cores as a System of Interrelated Technological Processes (based on materials from the Abadzekh site in the Maikop region)]. Voprosy arheologii Adygei. [Questions of Archaeology of Adygea]. Majkop : Adygejskoe knizhnoe izdatel'stvo, 1986. Pp. 79-92 (In Russ.)

Inizan M. L., Reduron-Ballinger M., Roche G., Tixier J. Technology and Terminology of Knapped Stone. Translated by J. Féblot-Augustins. Préhistoire de la Pierre Taillée T. 5. Nanterre : CREP, 1999. P. 189

Jöris O. Neue Untersuchungen zum Mittelpaläolithikum von Buhlen, Hessen. Technologische Studien zur Pradniktechnik in Horizont IIIb des Oberen Fundplatzes // Ethnographisch Archäologische Zeitschrift. 1994. № 35. Pp. 88-97.

Jöris O. Bifacially backed knives (Keilmesser) in the Central European Middle Palaeolithic // Axe age: Acheulian Tool-Making from Quarry to Discard / eds. by N. Goren-Inbar, G. Sharon. London, 2006. Pp. 287-310.

Kolobova K. A. Priemy oformleniya kamennyh orudij v paleoliticheskih industriyah Gornogo Altaya [Techniques for the Formation of Stone Tools in the Paleolithic Industries of Gorny Altai]. Novosibirsk : Izd-vo In-ta arheologii i etnografii SO RAN, 2006. (In Russ.)

Kolobova K. A., Krivoshapkin A. I., Shnaider S. V. Early Geometric Microlith Technology In Central Asia // Archaeological and Anthropological Sciences. 2018. №1. DOI: 10.1007/ s12520-018-0613-y

Kolobova K. A., Shalagina A. V., Chistyakov P. V., Bocharova E. N., Krivoshapkin A. I. Threedimensional Modelling Application for Studying Stone Age Assemblages // Siberian Historical Research. 2020. № 4. Pp. 240-260. DOI: 10.17223/2312461X/30/12

Kot M. A. The Earliest Middle Palaeolithic Bifacial Leafpoints in Central and Southern Europe. Technological Approach. PhD Thesis. Warsaw. 2013. P. 374

Kot M. A. The Earliest Middle Palaeolithic Bifacial Leafpoints in Central and Southern Europe: Technological Approach // Quaternary International. 2014. № 326-327. P. 381-397. DOI: 10.1016/j.quaint.2013.10.030

Lemorini C., Bourguignon L., Zupancich A., Gopher A., Barkai R. A Scraper's Life History: Morpho-Techno-Functional and Use-Wear Analysis of Quina and Demi-Quina Scrapers from Qesem Cave, Israel // Quaternary International. 2015. № 398. Pp. 1-8. 
Lyubin V.P. K voprosu o metodike izucheniya nizhnepaleoliticheskih kamennyh orudij [On the Question of the Method of Studying the Lower Paleolithic Stone Tools]. Paleolit i neolit SSSR [Paleolithic and Neolithic of the USSR]. Vol. V. Moscow; Leningrad : Nauka, 1965. Pp. 7-75 (In Russ.)

Nehoroshev P.E. Tehnologicheskij metod izucheniya pervichnogo rasshchepleniya kamnya srednego paleolita [Technological Method for Studying the Primary Cleavage of the Middle Paleolithic Stone]. Sankt-Peterburg : Evropeiskij dom, 1999. P. 172. (In Russ.)

Neruda P. Blank Length Reconstruction on the Base of Circular Segment Method -Core Refitting Case Study // Anthropologie (Brno). 2015. № 53 (3). Pp. 531-545.

Nerudova Z., Neruda P. Technology of Moravian Early Szeletian Leaf Point Shaping: A Case Study of Refittings from Moravský Krumlov IV Open-Air Site (Czech Republic) // Quaternary International. 2017. № 428. Pp. 91-108. DOI: 10.1016/j.quaint.2015.09.065

Ocherednoj A. K. Sistemy skalyvaniya v analize izgotovleniya dvustoronneobrabotannyh orudij [Chipping Systems in the Analysis of the Manufacture of Double-Sided Tools]. Trudy istoricheskogo fakul'teta Sankt-Peterburgskogo universiteta [Proceedings of the Faculty of History of St. Petersburg University]. 2014. № 18. Pp. 215-224. (In Russ.)

Pastoors A. Standardization and Individuality in the Production Process of Bifacial Tools - Leaf-Shaped Scrapers from the Middle Paleolithic Open Air Site Sare Kaya I (Crimea). In Neanderthals and Modern Humans - Discussing the Transition. Central and Eastern Europe from 50.000-30.000 B. P. Mettmann : Neanderthal Museum, 2000. Pp. 243-255.

Pastoors A., Schafer J. Analyse des états techniques de transformation, d'utilisation et états post dépositionnels. Illustrée par un outil bifacial de Salzgitter-Lebenstedt (FRG) // Préhistoire Européenne. 1999. № 14. Pp. 33-47.

Pavlenok G. D., Kozlikin M. B., Shunkov M. V. Small Blade Technology in the Early Upper Paleolithic Industries from Denisova Cave: Data from Analysis of a Lithic Reduction Sequence // Ural’skij Istoriceskij Vestnik. 2021. № 70 (1). Pp. 123-128

Pavlenok K. K., Belousova N.E., Rybin E. P. Atributivnyj podhod k rekonstrukcii "operacionnyh cepochek" rasshchepleniya kamnya [An Attributive Approach to the Reconstruction of "Operational Chains" of Stone Splitting]. Vestnik Novosibirskogo gosudarstvennogo universiteta. Ser.: Istoriya, filologiya [Bulletin of Novosibirsk State University Series: History, Philology]. 2011. Vol. 10. Issue 3. 2011. P. 35-46. (In Russ.)

Pavlenok G., Pavlenok K. Scar-Pattern Analysis of the Bladelet Cores from Layer 23 of Kulbulak Site // The Past has a Future! Conference to Mark the Centenary of Archaeology at the Institute of Archaeology, University of Warsaw (9-3.12.2019). Warsaw, 2019. Pp. 61-62.

Pelegrin J. Prehistoric Lithic Technology: Some Aspects of Research // Archaeological Review from Cambridge. 1990. № 9. Pp. 116-125.

Pigeot N. Reflexions sur l'histoire technique de l'homme: De l'evolution cognitive a l'evolution culturelle // Paleo 1991. № 3. Pp. 167-200.

Richter J. Une analyse standarisée des chaines opératoires sur les pièces foliacées du Paleolithique moyen tardif // L. Bourgignon, I. Ortega and M.-C. Frèresautot (eds). Préhistoire et approche expérimentale. 2001. Pp. 77-78.

Richter J. Copies of flakes: Operational Sequences of Foliate Pieces from Buran-Kaya III Level B1 // V. P. Chabai, K. Monigal and A. E. Marks (eds.). The Middle Paleolithic and Early Upper Paleolithic of Eastern Crimea 3. Liege : ERAUL 104, 2004. Pp. 233-247. 
Shalagina A. V., Kharevich V.M., Maury S., Baumann M., Krivoshapkin A. I., Kolobova K. A. Reconstruction of the Bifacial Technological Sequence in Chagyrskaya Cave Assemblage // Siberian Historical Research. 2020. № 3. Pp. 130-151. DOI: 10.17223/2312461X/29/9

Shalagina, A., Kolobova, K., Krivoshapkin, A. Scar Pattern Analysis as a Method for the Rreconstruction of Lithic Artifacts Production Sequence // Stratum Plus. 2019. № 1. Pp. 145-154.

Shalagina A. V., Krivoshapkin A.I., Kolobova K. A. Truncated-Faceted Pieces in the Paleolithic of Nothern Asia. Archaeology, Ethnology \& Anthropology of Eurasia. 2015. № 4(44). P. 33-45. DOI: 10.17746/1563-0102.2015.43.4.033-045

Soriano S., Villa P. Early Levallois and the Beginning of the Middle Paleolithic in Central Italy // PLoS One. 2017. № 12(10). e0186082. DOI:10.1371/journal.pone.0186082.

Scheer A.-W. ARIS - Modellierungsmethoden, Metamodelle, Anwendungen. Berlin Heidelberg : Springer-Verlag. 1998. DOI 10.1007/978-3-642-97731-2

Soriano S., Villa P., Delagnes A., Degano I., Pollarolo L., Lucejko J. J., Henshilwood Ch., Wadley L. The Still Bay and Howiesons Poort at Sibudu and Blombos: Understanding Middle Stone Age Technologies // PloS ONE. 2015. № 10 (7). P. 1-46.

Uthmeier Th. The Transition from Middle- to Upper Palaeolithic at Buran Kaya III, Crimea (Ukraine): a Case of Conceptual Continuity of Lithic Artefact Manufacture?» // A. Pastoors and M. Peresani (eds.). Flakes not Blades: The Role of Flake Production at the Onset of the Upper Palaeolithic. Mettmann: Wissenschaftliche Schriften des Neanderthal Museums 5, 2012. Pp. 239-260.

Uthmeier Th. Transformation Analysis and the Reconstruction of On-Site and Off-Site Activities: Methodological Remarks // V.P. Chabai, K. Monigal and A.E. Marks (eds.): The Middle Paleolithic and Early Upper Paleolithic of Eastern Crimea: The Paleolithic of Crimea III. Liege : ERAUL 104, 2004. Pp. 175-191.

Veselsky A.P. Kabazi V: Production and Rejuvenation of Bifacial Tools // Kabazi V: Interstratification of Micoquian \& Levallois-Mousterian Camp Sites. Palaeolithic Sites of Crimea. Vol. 3, Part 2. Simferopol; Cologne : Shlyakh, 2008. Pp. 455-479.

Wiśniewski A., Chłoń M., Weiss M., Pyżewicz K. Migal W. On Making of Micoquian Bifacial Backed Tools at Pietraszyn 49a, SW Poland // Journal of Paleolithic Archaeology. 2020. №3. Pp. 856-888.

Zwyns N. Laminar Technology and the Onset of the Upper Paleolithic in the Altai, Siberia (Studies in Human Evolution). Doctoral Thesis, Leiden : University Press. 2012. P. 414.

\section{БИБЛИОГРАФИЧЕСКИЙ СПИСОК}

Гиря Е. Ю. Технологический анализ каменных индустрий: Методика микро-макроанализа древних орудий труда. Ч. 2. СПб. : Изд-во ИИМК РАН, 1997. С. 199.

Дороничев В.Б. Изучение техники расщепления нуклеусов как системы взаимосвязанных технологических процессов (по материалам Абадзехского местонахождения в Майкопском районе) // Вопросы археологии Адыгеи. Майкоп : Адыгейское книжное издательство, 1986. С. 79-92.

Колобова К.А. Приемы оформления каменных орудий в палеолитических индустриях Горного Алтая. Новосибирск : Изд-во Ин-та археологии и этнографии СО РАН, 2006. 136 c. 
Любин В. П. К вопросу о методике изучения нижнепалеолитических каменных орудий // Палеолит и неолит СССР. Т. V. М.; Л. : Наука, 1965. С. 7-75.

Нехорошев П.Е. Технологический метод изучения первичного расщепления камня среднего палеолита. СПб. : Европейский дом, 1999. С. 172.

Очередной А. К. Системы скалывания в анализе изготовления двустороннеобработанных орудий // Труды исторического факультета Санкт-Петербургского университета. 2014. № 18. С. 215-224.

Павленок К.К., Белоусова Н.Е., Рыбин Е. П. Атрибутивный подход к реконструкции «операционных цепочек» расщепления камня // Вестник Новосибирского государственного университета. Сер.: История, филология. 2011. Т. 10. Вып. 3. С. 35-46.

Чабай В. П. Средний палеолит Крыма. Симферополь : Шлях, 2004. 324 с.

Bar-Yosef O., Van Peer P. The Chaine Operatoire Approach in Middle Paleolithic Archaeology // Current Anthropology. 2009. №1 (50). P. 103-131.

Boëda E. Determination des unités techno-fonctionnelles des pièces bifaciales provenant de la couche acheuléenne C'3 base du site de Barbas I // Les industries à outils bifaciaux du Paléolithique moyen d'Europe occidentale. Liège : Editions de l'Université de Liège, 2001. P. 51-75.

Boëda E., Geneste J. M., Meignen L. Identification de chaîne opératoires lithiques du Paléolithique ancien et moyen // Paléo. 1990. №2. P. 43-80.

Clarkson C., Vinicius L., Lahr M. M. Quantifying flake scar patterning on cores using 3D recording techniques // Journal of Archaeological Science. 2006. №33. P. 132-142.

Inizan M. L., Reduron-Ballinger M., Roche G., Tixier J. Technology and Terminology of Knapped Stone. Translated by J. Féblot-Augustins. Préhistoire de la Pierre Taillée T. 5. Nanterre : CREP, 1999. P. 189

Jöris O. Neue Untersuchungen zum Mittelpaläolithikum von Buhlen, Hessen. Technologische Studien zur Pradniktechnik in Horizont IIIb des Oberen Fundplatzes // Ethnographisch Archäologische Zeitschrift. 1994. №35. P. 88-97.

Jöris O. Bifacially backed knives (Keilmesser) in the Central European Middle Palaeolithic // Axe age: Acheulian tool-making from quarry to discard / eds. by N. Goren-Inbar, G. Sharon. London : Equinox Publishing, 2006. P. 287-310.

Kolobova K. A., Krivoshapkin A. I., Shnaider S. V. Early Geometric Microlith Technology In Central Asia // Archaeological and Anthropological Sciences. 2018. №1. DOI: 10.1007/ s12520-018-0613-y

Kolobova K. A., Shalagina A. V., Chistyakov P. V., Bocharova E. N., Krivoshapkin A. I. Threedimensional modelling application for studying stone age assemblages // Siberian Historical Research. 2020. № 4. C. 240-260. DOI: 10.17223/2312461X/30/12

Kot M. A. The Earliest Middle Palaeolithic Bifacial Leafpoints in Central and Southern Europe. Technological Approach. PhD Thesis. Warsaw. 2013. P. 374.

Kot M. A. The Earliest Middle Palaeolithic Bifacial Leafpoints in Central and Southern Europe: Technological Approach // Quaternary International. 2014. №326-327. P. 381-397. DOI: 10.1016/j.quaint.2013.10.030

Lemorini C., Bourguignon L., Zupancich A., Gopher A., Barkai R. A Scraper's life history: Morpho-techno-functional and use-wear analysis of Quina and demi-Quina scrapers from Qesem Cave, Israel // Quaternary International. 2015. №398. P. 1-8. 
Neruda P. Blank length reconstruction on the base of circular segment method - core refitting case study // Anthropologie (Brno). 2015. №53 (3). P. 531-545.

Nerudova Z., Neruda P. Technology of Moravian Early Szeletian leaf point shaping: A case study of refittings from Moravský Krumlov IV open-air site (Czech Republic) // Quaternary International. 2017. №428. P. 91-108. DOI: 10.1016/j.quaint.2015.09.065

Pastoors A. Standardization and individuality in the production process of bifacial tools leaf-shaped scrapers from the middle Paleolithic open air site Sare Kaya I (Crimea). In Neanderthals and Modern Humans - Discussing the Transition. Central and Eastern Europe from 50.000-30.000 B. P. Mettmann : Neanderthal Museum, 2000. P. 243-255.

Pastoors A., Schafer J. Analyse des états techniques de transformation, d'utilisation et états post dépositionnels. Illustrée par un outil bifacial de Salzgitter-Lebenstedt (FRG) // Préhistoire Européenne. 1999. №14. P. 33-47.

Pavlenok G., Pavlenok K. Scar-Pattern Analysis of the Bladelet Cores from Layer 23 of Kulbulak Site // The past has a future! Conference to Mark the Centenary of Archaeology at the Institute of Archaeology, University of Warsaw (9-3.12.2019). Warsaw, 2019. P. 61-62.

Pavlenok G. D., Kozlikin M. B., Shunkov M. V. Small blade technology in the early upper paleolithic industries from denisova cave: Data from analysis of a lithic reduction sequence // Ural'skij Istoriceskij Vestnik. 2021. № 70(1). P. 123-128.

Pelegrin J. Prehistoric lithic technology: Some aspects of research // Archaeological Review from Cambridge. 1990. №9. P. 116-125.

Pigeot N. Reflexions sur l'histoire technique de l'homme: De l'evolution cognitive a l'evolution culturelle // Paleo 1991. №3. P. 167-200.

Richter J. Une analyse standarisée des chaines opératoires sur les pièces foliacées du Paleolithique moyen tardif // L. Bourgignon, I. Ortega and M.-C. Frèresautot (eds). Préhistoire et approche expérimentale. 2001. P. 77-78.

Richter J. Copies of flakes: Operational Sequences of Foliate Pieces from Buran-Kaya III Level B1 // V. P. Chabai, K. Monigal and A.E. Marks (eds.). The Middle Paleolithic and Early Upper Paleolithic of Eastern Crimea 3. Liege : ERAUL 104, 2004. P. 233-247.

Shalagina A. V., Kharevich V.M., Maury S., Baumann M., Krivoshapkin A.I., Kolobova K. A. Reconstruction of the bifacial technological sequence in Chagyrskaya cave assemblage // Siberian Historical Research. 2020. № 3. P. 130-151. DOI: 10.17223/2312461X/29/9

Shalagina A., Kolobova K., Krivoshapkin A. Scar pattern analysis as a method for the reconstruction of lithic artifacts production sequence // Stratum Plus. 2019. № 1. P. 145-154.

Shalagina A. V., Krivoshapkin A.I., Kolobova K. A. Truncated-faceted pieces in the Paleolithic of Nothern Asia. Archaeology, Ethnology \& Anthropology of Eurasia. 2015. № 4 (44). P. 33-45. DOI: 10.17746/1563-0102.2015.43.4.033-045

Scheer A.-W. ARIS - Modellierungsmethoden, Metamodelle, Anwendungen. Berlin Heidelberg : Springer-Verlag, 1998. DOI 10.1007/978-3-642-97731-2

Soriano S., Villa P., Delagnes A., Degano I., Pollarolo L., Lucejko J. J., Henshilwood Ch., Wadley L. The Still Bay and Howiesons Poort at Sibudu and Blombos: understanding Middle stone age technologies // PloS ONE. 2015. №10 (7). P. 1-46.

Soriano S., Villa P. Early Levallois and the beginning of the Middle Paleolithic in central Italy // PLoS One. 2017. № 12 (10). e0186082. DOI:10.1371/journal.pone.0186082. 
Uthmeier Th. The Transition from Middle- to Upper Palaeolithic at Buran Kaya III, Crimea (Ukraine): a case of conceptual continuity of lithic artefact manufacture?" // A. Pastoors and M. Peresani (eds.). Flakes not Blades: The Role of Flake Production at the Onset of the Upper Palaeolithic. Mettmann : Wissenschaftliche Schriften des Neanderthal Museums 5, 2012. P. 239-260.

Uthmeier Th. Transformation Analysis and the Reconstruction of On-Site and Off-Site Activities: Methodological Remarks // V. P. Chabai, K. Monigal and A. E. Marks (eds.): The Middle Paleolithic and Early Upper Paleolithic of Eastern Crimea: The Paleolithic of Crimea III. Liege : ERAUL 104, 2004. P. 175-191.

Veselsky A.P. Kabazi V: Production and Rejuvenation of Bifacial Tools // Kabazi V: Interstratification of Micoquian \& Levallois-Mousterian Camp Sites. Palaeolithic Sites of Crimea. Vol. 3, Part 2. Simferopol; Cologne : Shlyakh, 2008. P. 455-479.

Wiśniewski A., Chłoń M., Weiss M., Pyżewicz K. Migal W. On Making of Micoquian Bifacial Backed Tools at Pietraszyn 49a, SW Poland // Journal of Paleolithic Archaeology. 2020. №3. P. 856-888.

Zwyns N. Laminar Technology and the Onset of the Upper Paleolithic in the Altai, Siberia (Studies in Human Evolution). Doctoral Thesis. Leiden : University Press. 2012. P. 414.

INFORMATION ABOUT THE AUTHORS / ИНФОРМАЦИЯ ОБ АВТОРАХ

Alena Vladimirovna Kharevich, a Junior Researcher at the Laboratory of Digital Archaeology at Institute of Archaeology and Ethnography of the Siberian Branch of the Russian Academy of Sciences, Novosibirsk, Russian Federation.

Харевич Алена Владимировна, младший научной сотрудник лаборатории цифровой археологии Института археологии и этнографии СО РАН, г. Новосибирск, Российская Федерация.

Ksenya Anatolievna Kolobova, Professor of Russian Academy of Sciences, Doctor of Historical Sciences, Head of Laboratory, Leading Researcher, Institute of Archaeology and Ethnography of the Siberian Branch of the Russian Academy of Sciences, Novosibirsk, Russian Federation.

Колобова Ксения Анатольевна, профессор РАН, доктор исторических наук, заведующий лабораторией, ведущий научный сотрудник Института археологии и этнографии СО РАН, г. Новосибирск, Российская Федерация.

Andrey Innokentyevich Krivoshapkin, Corresponding Member of the Russian Academy of Sciences, Doctor of Historical Sciences, Director of the Institute of Archaeology and Ethnography of the Siberian Branch of the Russian Academy of Sciences, Novosibirsk, Russian Federation.

Кривошапкин Андрей Иннокентьевич, член-корреспондент РАН, доктор исторических наук, директор Института археологии и этнографии СО РАН, г. Новосибирск, Российская Федерация.

Материал поступил в редколлегию 05.07. 2021.

Статья принята в номер 30.08.2021. 